abweichenden duffassungen recht ansführlich referiert hat. yibt Verf. hegründeterweise einer solchen Rode, die neben den Eigenschaften der indirekten Rede auch solche der direkten Rede enthält, den Namen sekaesitys, vermischte Rede, oratio mixta. Er ist der Ansicht, der schriftsprachliche Gebrauch dieser Darstellungsilrt, die als Untergattung der oratio obliqua zu gelten hat, beruhe auf der Sprache des Volkes, wo die oratio mixta wegen ihrer Direktheit und ihrer Anschanlichkeit weitans allgemeiner ist als die reine oratio obliqua.

Eine solche in der Belletristik auftretende trt des Referats. wo der Schriftsteller die (redanken einer von ihm geschilderten liestalt gleichsam von deren Standpunkt aus, indem er sich intensiv in deren Rolle versetzt, darstellt, nennt Ikola die erlebte Rede. Z.B. Hiltu ei voinut olla pirtissä; hän katseli sinertävää metsänrantaa, jonka taakse haalea, knuma taivas painautui. Jotain itkun tapaista jutkahti hänen kurkussaan. Siellä jossain etäällä kaljupäinen isä kuljeskeli. Kalle oli lähtenyt lotoa jo kanan sitten ja Ville oli äsken kuollut pirlissä. 'Hiltu hielt es nicht mehr in der Stube aus; sie blickte nach dem bläulichen Waldrand hin, wo der verblichene, heisse Himmel verschwand. Etwas wie ein schluchzen blieb ihr in Ilalse stecken. Dort irgendwo, weit weg, trieb sich ihr kahlköpfiger Vater herum. Kalle hatte sich schon längst auf und davon gemacht und Ville war soeben in der Stube gestorben.' Seines Erachtens ist dir trlebte Rede grammatisch gesthen keine besondere Form des Reforats, sonderm ein rein stilistischer Begriff. Formal handelt es sich immer um die oratio obliqua oder oratio mixta.

Ikolas Untersuchung ist ausser in rein sprachwissenschaftlicher Hinsicht auch vom Standpunkt des praktischen Sprachgebrauchs wertvoll. Manche Einzelheiten des Sprachgebrauchs, die früher vielleicht für selbstverständlich galten, kommen dadurch in ein neues licht.

\title{
Mikko Konhoskx
}

()suo lkola, laanseopillisia havaintuja Georg Müllerin virolaisten saarnojen $(1600-1606)$ kielestä. Turku University Publications B 82. T'urkı 1962.

Mr. Osiro Ikola has made quite remarkable work in studying varions problems in the field of Finnish syntax, including syntactical relations in old literary Finnish. In his latest work, he turns his attention to the only other branch of Balto-Finnic which has some recorded historical evidence to show, that is, 
Fstonian. The rollected sermons of lieorg Müller is the richest monmment of old literary Estonian. In quality, they are not equal to Agricola's comparatively finished and outstudied achievements. but they were not either composed with publication in mind. The uneveness of the language is only an adrantage, from the scholar's point of view, as it may well be supposed to reflect the varieties of spoken Estonian.

The author has followed a selective and descriptive method and has concentrated on points in which Müller's language differs from present-day standard Estonian. The deviations are probably due to four different factors: 1. The archaic character of the language. 2. The dialect of Tallinn. 3. Müller's native language, viz. German. 4. His defective knowledge of Estonian. As mentioned by the author in the Preface, Müller could consult handwritten Estonian trxts, which represent a dialectically very varied background. If he relied on the speech of a native informant, this person probably spoke the Tallimn dialect, the influence of which is strongest on Müller's language. The Estonian text is scattered with quotations in German or I atin, inserted rather skilfully in the general structure of the sentences. Towards the end, the quotations increase in number. 'l'his is supposed to be due to Mïller's improved knowledge of Estonian: he did not find it necessiry to have his sermons completely translated, as he was able to refresh his memory with the help of German notes.

Mr. Ikola gives a detailed and careful analysis of Müller's language, considering both the grammatical rules given in old Estonian Irammars and the corresponding phenomena in present-day Estonian dialects. 'This contemporary backgromnd is a special merit of Mr. Ikola's method. As in most treatises concerning syntactical phenomena. congruency is the central problem, whether it appears in the adjective attribute and its main word, in the subject and the predicate, in the negative verb and the primary verb, in the transitive verb and its object. The adjective attribute follows its main word in nominative, genitive, partitive, elative, allative, adessive and translative, i.e. in the grammatical cases which occur most frequently in the text. In other cases, the attribute probably represents either the genitive form or the weak-grade stem; from a descriptive point of view, either interpretation conld be justified. - As to the relations of subject and predicate, when a singular nominative subject, contrary to present usage, occurs with a predicate in plural form, the word is usually a collective substantive or a numeral, and conceived as referring to many. - In Müller's sermons, the passive voice is a direct translation 
flom Crepman, as indicated in old Fstoniau grammars: MHinna silhn armastut. Ich werde geliebt." $A$ s, in Balto-Finnic, the passive is not personal in the Indo-European semse, but an indefinite roice, it is not an equivalent of Crerman passive expressions. The author remin'ks that, in Müller's texts, thr perfect and pluperfect passive mare expressed as in presentday Estonian by combining the verb olemu in the present or past tense with the past participle of the verb in question." As it is, the construction is not necrissarily a passive, but a case of copula and nominal predicate. - In the chapter dealing with the negative verb, the author expresses the opinion that, in Müller's language, the word $e y$ is not a negration, but a confirmatory interjection, since it occurs also in purely positive sentences (p. 59). Could it possibly be interpreted to be a ntegative interjection in sentences as "wey se eb siirry mitte ilmil lumala tädtmatta" (cf. nein - nicht)?

From a strictly descriptive point of view, one might remark that the author uses the term "accusative" in two senses, according to common use: syntactically, to indicate the total object, and morphologically, as the name of a (nonexistent) (ase. Synchronically speaking, maccusativen in Balto-Fimnic languages is a syntactical notion, not taking into account the restricted Finnish accusative in $t$. This same remark was made already by F. Wiedemann (trammatik der esthnischen Sprache, 1). 253).

In Mr. lkula's analysis, no comparison is made between the old Estonian and the old Finnish literary languages, for which, naturally, Müller's collection would not provide a basis wide enough. Nevertheless, his work opens interesting perspectives for the study of syntactical relations in the Balto-Finnic languages.

Heva KaNgasmat-MiNe

THomas A. SEBEok and VAlDIS J. Zers, concordance and Thrsaurus of Cheremis Poetic langulage. Mouton E Co. 's-(iratvenhage $1961.259 \mathrm{p}$.

Among the Finno-Ugrian languiges, ('heremis seems to have become a kind of favourite in modern American linguisties. Jany papers and monographs on the (hermmis language and popular civilization have been published from 1950 on by the Finno-ngrists beyond the ocean. The concordance and thesaurus presented here are closely comnected with this research work. 'The authors of the work have undertaken to compile a dic- 